\title{
The chemical reagents influence on the regulation of the powder composite materials setting time for construction purposes
}

\author{
Zokirkhan Munavvarkhanov", Rustam Soliyev, and Murotbek Boydadayev \\ Namangan Engineering Construction Institute, Namangan, Uzbekistan
}

\begin{abstract}
Additives were selected, and a method for modifying the structure of gypsum-containing materials for construction purposes and a method for their dispersion were developed. Based on the selected modifiers, effective compositions of composite gypsum-containing materials based on local and secondary raw materials were developed. An increase in their strength and resistance to water was established. The use of gypsum plaster mixes shows their high efficiency and advantages compared to traditional finishing works methods. They provide a high and stable level of finishing quality, reduced transportation costs, and easy recycling of materials. However, despite the high consumer properties, the modern use of compositions based on the most affordable gypsum raw materials in the Republic and the production of gypsum binder beta calcium sulfate semi hydrate is limited to plasters and putties for rooms with normal operation. This is mainly because the compositions have a short setting time, low water resistance, and low strength characteristics. As a rule, the softening factor for such compositions does not exceed 0.5 , and the compressive strength is 4-6 MPa
\end{abstract}

\section{Introduction}

In recent years, based on new developments, innovative projects, and rapid development of construction, there has been a radical reassessment of approaches to the choice of materials used in construction. Quality, reliability, and durability are the requirements that modern building materials must meet. In scientific centers and higher educational institutions of the world, research works are carried out in the field of developing compositions and technologies for producing modified composite materials, including composite gypsumcontaining materials based on natural raw materials and industrial waste, to create new building materials, such as the University of Tokyo (Japan), New-York State Institute (USA), KNAUF, Claudius Peters, Weimar State Construction University (Germany), Neopol II University (Italy), Moscow State University of Civil Engineering, Institute of Materials Science of the Russian Academy of Sciences (Ukraine).

Dry building mixes (DBM) are powdered compositions consisting of a mineral binder or polymer binder, fillers, additives (modifiers, antifreeze polymers, dyes, etc.) prepared in

\footnotetext{
* Corresponding author: murotboy@mail.ru
} 
the factory. At the worksite, the DBM is only diluted with water to a given ratio or consistency and used according to its application. Dry mixes are a set of ingredients prepared in the factory: mineral binders, fillers, and fillers of fixed dispersion, dispersion polymer powders, and various modifying additives.

Most raw materials for the production of dry mixes - gypsum binders, Portland cement, lime, pozzolan additives, fillers, and aggregates-are produced by the domestic industry. The exceptions are dispersed polymer powders and modifying chemical additives. However, in combination with binders, they realize their unique properties, giving solutions fundamentally new and important properties.

The main task of improving the technological processes for the production of modified composite gypsum-containing materials based on local and secondary raw materials is to improve their quality and give them all the necessary properties, which can be achieved by creating crystal hydrate neoplasms of increased strength and density through the selection of compositions and the introduction of special complex modifying chemical additives.

\section{Methods}

Gypsum binders from palpitates are quick-setting binders. Their setting begins in 2-6 minutes after closing. The setting time, they are divided into early (A) since the beginning of the setting, not earlier than 2 minutes and not later than $15 \mathrm{~min}$, normalerweise (B) for the beginning of the setting, not earlier than $6 \mathrm{~min}$. and end no later than 30 minutes and melanotaeniidae (In) - the beginning of setting no earlier than 20 min [39]. The setting time of gypsum depends on many technological factors. The increase in fineness of grind leads to a faster setting, and increasing the fineness of the raw plaster effect is much smaller than the secondary grinding of calcined gypsum. This is because after grinding the burnt gypsum, the dehydrate that was in the core of the grains begins to affect the setting processes. The setting time is extended when the temperature decreases to $10^{\circ} \mathrm{C}$. Temperature rise to $40-50^{\circ} \mathrm{C}$ leads to an acceleration of the setting time. An increase in the water-gypsum ratio leads to a slowdown in the setting time (Table 1).

Table 1. Influence of the water-gypsum ratio on the setting time

\begin{tabular}{|c|c|c|c|c|}
\hline Water-gypsum ratio, W/G & 0.55 & 0.65 & 0.75 & 0.85 \\
\hline Setting time, min & & & & \\
\hline - start & 9 & 11 & 14 & 16 \\
\hline - finish & 28 & 37 & 45 & 48 \\
\hline
\end{tabular}

When using fillers, the setting time is also slowed down. In our work, we tested gypsum compositions based on semi-aqueous gypsum and such fillers as fluff lime, marble flour, and fine quartz sand. The test results are shown in Table 2. 
Table 2. Influence of fillers and aggregates on the setting time of gypsum binder

\begin{tabular}{|c|c|c|c|c|c|c|}
\hline \multicolumn{2}{|c|}{ The ratio of components } & \multicolumn{2}{|c|}{ Setting time, min } & \multirow{2}{*}{$\mathrm{W} / \mathrm{G}$} & \multirow{2}{*}{$\begin{array}{c}\text { Adhesive } \\
\text { strength, } \mathrm{MPa}\end{array}$} & \multirow{2}{*}{$\begin{array}{c}\text { Compressi } \\
\text { ve strength, } \\
\mathrm{MPa}\end{array}$} \\
\hline Gypsum & Marble flour & start & finish & & & \\
\hline 100 & - & 10 & 14 & 0.65 & 0.3 & 3.9 \\
\hline 90 & 10 & 18 & 21 & 0.65 & 0.5 & 5.2 \\
\hline 80 & 20 & 20 & 24 & 0.65 & 0.54 & 4.9 \\
\hline 70 & 30 & 26 & 30 & 0.70 & 0.61 & 4.3 \\
\hline 60 & 40 & 26 & 31 & 0.74 & 0.63 & 4.1 \\
\hline 50 & 50 & 29 & 36 & 0.76 & 0.58 & 3.9 \\
\hline 40 & 60 & 29 & 38 & 0.85 & 0.55 & 3.8 \\
\hline Gypsum & Lime- fluff & & & & & \\
\hline 98 & 2 & 15 & 18 & 0.69 & - & 3.9 \\
\hline 96 & 4 & 22 & 24 & 0.70 & - & 4.8 \\
\hline 92 & 8 & 25 & 28 & 0.72 & - & 4.1 \\
\hline 90 & 10 & 28 & 31 & 0.74 & - & 4.0 \\
\hline Gypsum & Sand & & & & & \\
\hline 97 & 3 & 12 & 16 & 0.65 & 0.45 & 4.0 \\
\hline 95 & 5 & 16 & 20 & 0.65 & 0.48 & 4.6 \\
\hline 92 & 8 & 18 & 24 & 0.65 & 0.51 & 4.8 \\
\hline 90 & 10 & 20 & 22 & 0.65 & 0.52 & 4.4 \\
\hline 88 & 12 & 20 & 23 & 0.70 & 0.54 & 4.4 \\
\hline
\end{tabular}

As such additives, we used additives under the conventional name: additive $\mathrm{A}$ and additive B.

Additives that regulate the speed of the gypsum binder were introduced into the pure gypsum binder (Table 3 ) and in the composition, i.e., a dry construction mixture consisting of $60 \%$ construction gypsum and $40 \%$ marble flour (Table 4 ).

Table 3. Effect of chemical modifying additives on the setting rate of pure gypsum binder

\begin{tabular}{|c|c|c|c|c|c|c|}
\hline \multirow[t]{2}{*}{$\begin{array}{l}\text { Experience } \\
\quad №\end{array}$} & \multicolumn{2}{|c|}{$\begin{array}{l}\text { Quantity of } \\
\text { additive, \% } \\
\text { by weight of } \\
\text { gypsum }\end{array}$} & \multicolumn{2}{|c|}{$\begin{array}{l}\text { Setting time, } \\
\text { h-min }\end{array}$} & \multirow[t]{2}{*}{$\mathrm{W} / \mathrm{G}$} & \multirow[t]{2}{*}{ Note } \\
\hline & $\mathrm{A}$ & $\mathrm{B}$ & start & finish & & \\
\hline 7 & - & - & $0-10$ & $0-14$ & 0.65 & \\
\hline 8 & 0.6 & - & $1-25$ & $3-10$ & 0.65 & $\begin{array}{l}\text { there is a lot of water; there is no } \\
\text { strength }\end{array}$ \\
\hline 9 & 0.6 & - & $1-50$ & $2-40$ & 0.55 & increasing the sample volume \\
\hline 10 & 0.3 & - & $1-09$ & $2-08$ & 0.55 & increasing the sample volume \\
\hline 11 & 0.15 & - & $1-16$ & $1-45$ & 0.55 & the increase in sample no \\
\hline 12 & 0.1 & - & $1-15$ & $1-35$ & 0.55 & $\begin{array}{l}\text { no magnification, reaches for } \\
\text { the spatula }\end{array}$ \\
\hline 17 & - & 0.1 & $0-11$ & $0-15$ & 0.65 & $\begin{array}{l}\text { the additive was introduced } \\
\text { with mixing water }\end{array}$ \\
\hline 18 & - & 0.2 & $0-12$ & $0-17$ & 0.66 & $-\ll-$ \\
\hline 19 & - & 0.5 & $0-35$ & $0-55$ & 0.65 & $\begin{array}{l}\text { the mixture is plastic, does not } \\
\text { reach for the spatula, there is } \\
\text { water separation }\end{array}$ \\
\hline 20 & - & 1.0 & $2-10$ & $2-40$ & 0.65 & $\begin{array}{l}\text { the mixture is plastic, does not } \\
\text { reach for the spatula, there is no } \\
\text { water separation }\end{array}$ \\
\hline
\end{tabular}


As can be seen from the results shown in Table 4, additive A, introduced into the composition of pure gypsum binder in an amount of more than $2 \%$, leads to a significant increase in the volume of the hardened stone. The water-gypsum ratio decreases from 0.65 to 0.55 , which leads to an increase in the density and strength of the solidified mass. However, when applying the mass to the surface, the mixture stretches behind the spatula, forming lumps. The beginning of setting increases to 1 hour 15 minutes, the end almost to 3 hours, making it possible to use the prepared gypsum mixture for a long time.

The introduction of a chemical modifying additive $\mathrm{B}$ is made in the mixing water. To do this, the required amount of water is measured, a chemical modifying additive B is poured into it, left for 30-45 minutes with stirring, and then the prepared solution is used to seal the gypsum binder. The amount of the additive was from 0.1 to $1.0 \%$ by weight of the gypsum. From the above data, it can be seen that the addition of B practically does not affect the water-gypsum ratio. The effect on the setting time is provided by an additive in more than $0.5 \%$ of the mass of gypsum. At the same time, the beginning of the setting is 35 minutes, and the end is 55 minutes. During the hardening of the gypsum dough, water separation occurs. The mixture is easy to move, elastic when applied to the surface does not reach for the spatula. With an increase for additive to $1.0 \%$, the beginning of setting slows down sharply and is 2 hours 10 minutes, and the end is 2 hours 40 minutes. The mixture is easily movable, does not reach for the spatula, the hardened mortar has significant strength, and adheres well to the surface of concrete, brickwork.

The results obtained in the study of the effect of additives on the setting rate of a gypsum composition consisting of $40 \%$ marble flour and $60 \%$ semi-aqueous gypsum are presented in Table 4.

As can be seen from the data given in the tables, with the introduction of chemical modifying additives of type A and type B, the terms are set, significantly increase, the vitality of the resulting solution from the gypsum dry composition increases, the mortar mixture becomes elastic, easily movable, easily applied to the treated surface, well adheres to concrete and brick. 
Table 4. Effect of chemical modifying additives on the setting rate and other properties of the gypsum composition

\begin{tabular}{|c|c|c|c|c|c|c|}
\hline \multirow[t]{2}{*}{$\begin{array}{c}\text { Exper } \\
\text { ience } \\
\text { No. }\end{array}$} & \multicolumn{2}{|c|}{$\begin{array}{c}\text { Quantity of } \\
\text { additive, } \% \text { by } \\
\text { weight of gypsum }\end{array}$} & \multicolumn{2}{|c|}{$\begin{array}{l}\text { Setting time, } \\
\text { h-min }\end{array}$} & \multirow[t]{2}{*}{$\mathrm{W} / \mathrm{G}$} & \multirow[t]{2}{*}{ Note } \\
\hline & A & B & start & finish & & \\
\hline 7 & - & - & $0-10$ & $0-14$ & 0,65 & \\
\hline \multicolumn{7}{|c|}{ Composition of $60 \%$ gypsum and $40 \%$ marble flour } \\
\hline 21 & - & 1.0 & $0-29$ & $0-35$ & 0.75 & not enough water \\
\hline 22 & - & 1.0 & $0-38$ & $0-54$ & 0.77 & $\begin{array}{l}\text { there is not enough water; } \\
\text { there is water separation }\end{array}$ \\
\hline 23 & - & 1.0 & $1-00$ & $1-30$ & 0.95 & $\begin{array}{l}\text { there is a lot of water; the } \\
\text { solution is plastic, does } \\
\text { not reach for the spatula, } \\
\text { there is water separation }\end{array}$ \\
\hline 11 & 0.15 & - & $0-50$ & $1-05$ & 0.74 & $\begin{array}{l}\text { water separation is } \\
\text { underway; reaches for the } \\
\text { spatula }\end{array}$ \\
\hline 12 & 0.1 & - & $0-56$ & $1-04$ & 0.74 & $\begin{array}{l}\text { water separation is } \\
\text { underway; reaches for the } \\
\text { spatula }\end{array}$ \\
\hline 14 & 0.2 & - & $0-56$ & $1-05$ & 0.74 & $\begin{array}{c}\text { water separation is } \\
\text { underway; reaches for the } \\
\text { spatula }\end{array}$ \\
\hline 15 & 0.3 & - & $1-14$ & $1-29$ & 0.74 & $\begin{array}{l}\text { there is water separation, } \\
\text { high adhesion does not } \\
\text { reach for the spatula }\end{array}$ \\
\hline 16 & 0.4 & - & $2-00$ & $2-30$ & 0.74 & $\begin{array}{l}\text { the mixture is elastic, } \\
\text { does not stretch behind } \\
\text { the spatula, high adhesion }\end{array}$ \\
\hline
\end{tabular}

When drying, there are no shrinkage cracks on the surface of the plastered layer; the surface is well treated with paints and whitewash.

\section{Results and Discussion}

Based on the conducted physic-chemical studies, it was found that the content of calcium sulfate dehydrate phosphorite phosphogypsum, according to the standard, can be attributed to first-class or second-class gypsum raw materials but impurities significantly change its properties. Neutralization of acidic impurities of phosphorite phosphogypsum will make it possible to obtain high-quality gypsum binders and sulfate-containing composite building materials for the construction industry.

It is established that the temperature of dehydration sulfate raw materials (calcium sulphate dihydrate) depends on the content of calcium sulphate dehydrate, humidity and finenesses starting material, and temperature of heat treatment. The process of dehydration of phosphogypsum occurs at a temperature of $175^{\circ} \mathrm{C}$, for an hour with the formation of calcium sulfate semi hydrate, which has a set start of 7 minutes, the end-10 minutes. The strength of the samples at a normal density of $56 \%$ after 2 hours of hardening is 4.5 ; after 1 day $-6.5 ; 7$ days -11.7 and 28 days $-12.9 \mathrm{MPa}$.

Heating the phosphogypsum to $800^{\circ} \mathrm{C}$ in the presence of a sodosulfate alloy activator in an amount of $3.0 \%$ of the phosphogypsum mass for 60 minutes results in an anhydrite 
binder having a set start of 15 minutes, a setting end of 31 minutes, compressive strength of 30.0 MPa after 28 days of hardening, and a bending strength of 17.7 MPa.

To obtain high-quality gypsum-containing materials for construction purposes, quartz sand of a fraction less than $0.1 \mathrm{~mm}$ and marble chips of a fraction of $0.1 \mathrm{~mm}$ can be used as a filler $-2 \mathrm{~mm}$. The optimal amount of fractionated sand is $10-15 \%$ of the mass of natural gypsum and no more than $10 \%$ - for gypsum from phosphogypsum because phosphogypsum contains fine silica in the form of impurities.

The amount of marble chips introduced for natural gypsum is $20 \%$, and for gypsum from phosphogypsum- $15 \%$ of the weight of the binder.

The developed compositions of gypsum-containing materials for construction purposes have high strength, good adhesion to the treated surface, and can be used for interior decoration of buildings and structures with dry and normal indoor conditions.

The disadvantages of the developed compositions are increased water demand and low softening coefficient, i.e., low water resistance.

To reduce water demand and increase the plasticity of gypsum-containing materials for construction purposes, a domestic surfactant in the form of OGS-1 was selected, which was introduced into the composition when grinding the binder in an amount of $3 \%$ of the mass of gypsum. At the same time, there was a decrease in water demand from 56 to $35 \%$, which contributes to an increase in the strength and density of the hardened gypsum stone.

To increase the water-resistance of gypsum-containing materials for construction purposes, the technology for producing gypsum binders from phosphogypsum was chosen by joint hydrothermal treatment in an autoclave of phosphogypsum, Portland cement, pozzolan additive, lime, and a crystallization regulator.

The test results showed that the gypsum-containing material of the composition, wt.\%: gypsum-56, Portland cement-25, pozzolanic additive-18 has a water demand of $44 \%$, the beginning of setting is 9 minutes, the end of setting is 22 minutes, the compressive strength after 1.5 hours of hardening is $4.5 \mathrm{MPa}$, after 28 days-28 MPa. The softening factor is 0.70 , which indicates its high water resistance.

\section{Conclusions}

The developed composition of the water-resistant gypsum-containing material has such a disadvantage, with a short start and end time of its setting; it does not make it possible to make large mixes to perform a large amount of work.

To lengthen the time of the beginning and end of setting, chemical additives of local production, conventionally called "Additive A" and "Additive B," were used, which were introduced into the composition of the gypsum-containing water-resistant material during the grinding of the binder, or with mixing water. It was found that the introduction of "Additive $\mathrm{A}$ " for $0.6 \%$ of the mass of gypsum lengthens the setting time, which is the beginning - 1 hour 50 minutes, the end - 2 hours 40 minutes. At the same time, a slight increase in the volume of the sample was noted. At the same time, water demand decreased from 65 to $55 \%$.

\section{References}

1. Negmatov S.S., Salimsakov Yu.A., Issledovanie varochnyx i fiziko-khimicheskix svoystv mestnyx bazaltovyx porod Kompozitsionnye materialy, № 2, p. 44, (2003)

2. Ruzieva B.Yu., Negmatov S.S. Prospects for the use of basalt ingredients in the development of composite materials, Compositional materials, № 2 p. 60, (2004)

3. Akbarov I.G., Negmatov S.S., Boydadaev M.B., Issledovanie osobennostey i fizikokhimicheskix svoystv nemodifitsirovannyx neftyanyx bitumnyx materialov, 
Universum: Texnicheskie nauki: elektron. nauchn. jurn. № 2 (71). (2020) URL: http://7universum.com/ru/tech/archive/item/8809

4. Kosukhin M. M., Ogrel L. Yu., Pavlenko V.I., Shapovalov I.V., Bio-resistant cement concretes with polyfunctional modifiers Construction materials, 11, pp. 48-49, (2003)

5. Fedorov P.I., Makarov N. P., Bogdanov V.F., Ushakov S.M., Eneikin., Yu. S., Slastnikov N.I., Natural biocides for concrete. International. Congress, Modern technologies in the industry of building materials and construction industry, Belgorod, (2003).

6. Nasledskova O.A., Morozov D.A., Zakharova E.A., Erofeev V.T., Smirnov V.F. Investigation of the effect of sulfochlorantin-D additives and the biocide "Gidol" on the fungal resistance of cement composites, All-Russian STC "Modern technologies of building materials and structures", dedicated to. 150th anniversary of the birth of Academician V. G. Shukhov, Saransk, pp. 95-98, (2003)

7. Bargov E.G., Erofeev V.T., Nasledkova A.A. Biological resistance of foam concrete in buildings with biologically active environments, All-Russian STC "Modern technologies of building materials and structures", dedicated to. 150th anniversary of the birth of Academician V. G. Shukhov, Saransk, pp. 294-296, (2003)

8. Gavrilenko G.N., Tomarovskaya E.S. Biostoyky modified concretes for wet hot climate conditions, All-Russian STC "Modern technologies of building materials and structures", dedicated to the 150th anniversary of the birth of Academician Shukhov V. G.-Saransk, pp. 13-17, (2003)

9. Bazhenov Yu.M., Erofeev V.T., Smirnov V.F., Bogatov A.D., Morozov E.A. Composites with increased biological resistance. International. NC "Fundamental problems of integrated use of natural and man-made raw materials of the Barents region in the technology of building materials", Apatity, 1-4 Apr. 2003. Publishing House of KNTSRAN, pp. 170-172, (2003)

10. Erofeev V.T., Morozov E. A. Study of biodegradation of cement composite materials by mathematical modeling //Construction materials, (7). p. 5-7. (2006).

11. Boldyrev V.V. Mechanochemistry mechanical activation of solid substances, Uspekhi khimii, 75, (3). pp, 203-216. (2006).

12. Mankevich Ya.V., Sycheva L.I., Influence of mechanical activation of phosphogypsum raw mixture on hydration and hardening of anhydrite binder, Advances in chemistry and chemical technology. T. XXU111. 8, pp. 96-99, (2014)

13. Suchkov V.P. Mechanochemical activation in the technology of processing gypsum raw materials, Bulletin of SHASU. Urban Planning and Architecture, (4). pp. 82-86, (2011)

14. Bagdasarov A.S. Energy - and resource-saving technologies for the production of construction products based on industrial waste, Cherkessk, p. 21, (2013)

15. Fedorkin S.I., Lyubomirsky N.V., Bratkovsky R.V. Wall material of increased water resistance based on phosphogypsum, construction and technogenic safety, 9, pp. 8890. (2004)

16. Vinnichenko V.I., Krainov P.P., Ivashchenko T.G., Filin V.N., Lisin D.V., Zhegus Yu.N. Technologies for processing phosphogypsum into gypsum binders, Ecology and Industry, (2), pp. 66-71, (2009)

17. Tersin V.A., Troshin M.A., Gypsum, its research and application Mir sery, (6), pp. 1013, (2005)

18. Denev Y.G., Denev G.D., Popov A.N. The use of phosphogypsum as a light mineral filler for elastomers / / Chemical industry today,(6). pp. 34-38. (2008).

19. Meshcheryakov Yu.G., Fedorov S.V. Energy-saving technologies for processing phosphogypsum and phosphopoluhydrate, Construction materials, (11), pp. 56-57, (2005) 
20. Boydadayev M. B., S. S. Negmatov., Z. T. Munavvarkhanov, A. Sh. Nasriddinov. Production technology of wood-plastic composite materials plate materials based on fillers. Universum: Technical Sciences-Moscow, 12 (69), pp. 58-61., DOI: 10.32743/UniTech.2019.69.12-1. (2019) 